\title{
1 Enzyme specific isotope effects of the Nap and Nar nitrate
}

\section{2 reductases}

3 Ciara K. Asamoto ${ }^{1}$, Kaitlin R. Rempfert ${ }^{1}$, Victoria H. Luu ${ }^{2}$, Adam D. Younkin ${ }^{1}$, Sebastian H.

$4 \mathrm{Kopf}^{1}$

$5 \quad{ }^{1}$ Department of Geological Sciences, University of Colorado Boulder, Boulder, CO 80309

$6 \quad{ }^{2}$ Department of Geosciences, Princeton University, Princeton, NJ 08544

\section{Abstract}

Dissimilatory nitrate reduction (DNR) to nitrite is the first step in denitrification, the main process through which bioavailable nitrogen is removed from ecosystems. DNR fractionates the stable isotopes of nitrogen $\left({ }^{14} \mathrm{~N},{ }^{15} \mathrm{~N}\right)$ and oxygen $\left({ }^{16} \mathrm{O},{ }^{18} \mathrm{O}\right)$ and thus imparts an isotopic signature on residual pools of nitrate in many environments. Data on the relationship between the resulting isotopic pattern in oxygen versus nitrogen isotopes $\left({ }^{18} \varepsilon /{ }^{15} \varepsilon\right)$ suggests systematic differences exist between marine and terrestrial ecosystems that are not fully understood. DNR can be catalyzed by both cytosolic (Nar) and periplasmic (Nap) nitrate reductases, and previous work has revealed differences in their ${ }^{18} \mathcal{E} /{ }^{15} \varepsilon$ isotopic signatures. In this study, we thus examine the ${ }^{18} \varepsilon /{ }^{15} \varepsilon$ of six different nitrate-reducing microorganisms that encode Nar, Nap or both enzymes, as well gene deletion mutants of the enzymes' catalytic subunits (NarG and NapA) to test the hypothesis that enzymatic differences alone could explain the environmental observations. We find that the distribution of the ${ }^{18} \varepsilon /{ }^{15} \varepsilon$ fractionation ratios of all examined nitrate reductases form two distinct, non-overlapping peaks centered around a ${ }^{1{ }^{18}} \varepsilon /{ }^{15} \varepsilon$ proportionality of 0.55 and a ${ }^{18} \varepsilon /{ }^{15} \varepsilon$ proportionality of 0.91 , respectively. All Nap reductases studied to date cluster around the lower proportionality (0.55) and none exceed a ${ }^{18} \varepsilon /{ }^{15} \varepsilon$ proportionality of 0.68 . Almost all Nar reductases, on the contrary, cluster tightly around the higher proportionality $(0.91)$ with no values below a ${ }^{18} \varepsilon /{ }^{15} \varepsilon$ proportionality of 0.84 with the notable exception of the Nar reductases from the genus Bacillus which fall around 0.62 and thus closely resemble the isotopic fingerprints of the Nap reductases. Our findings confirm the existence of two remarkably distinct isotopic end-members in the dissimilatory nitrate reductases that could indeed explain differences in coupled $\mathrm{N}$ and $\mathrm{O}$ isotope fractionation between marine and terrestrial systems, and almost but not fully match reductase phylogeny. 


\section{Introduction}

33 Nitrogen is an essential nutrient for life and consequently the availability of nitrogen is a vital

34 control on ecosystem productivity. Anthropogenic activity has severely altered the natural

35 balance of the nitrogen cycle. In particular, the use of the Haber-Bosch reaction to synthesize

36 fertilizers has resulted in excess amounts of nitrate and ammonium being introduced into

37 ecosystems ${ }^{1,2}$. Assessing the outcomes of excess nitrogen inputs into ecosystems requires a

38 mechanistic understanding of the competing processes that affect nitrogen cycling in the

39 environment.

41 Fig. 1A highlights key reductive and oxidative steps in the nitrogen cycle, all of which are

42 catalyzed by microorganisms ${ }^{3}$. The enzymes bacteria use to reduce or oxidize nitrogen

43 intermediates in the nitrogen cycle impart a kinetic isotope effect on the stable isotopes of

44 nitrogen $\left({ }^{14} \mathrm{~N},{ }^{15} \mathrm{~N}\right)$ and oxygen $\left({ }^{16} \mathrm{O},{ }^{18} \mathrm{O}\right){ }^{4-9}$. Because nitrogen fixation by most nitrogenases

45 does not impart strong isotopic fractionation ${ }^{9-13}$, redox cycling of fixed nitrogen, especially the

46 isotopic fractionation associated with dissimilatory nitrate reduction to nitrite, controls the

47 isotopic composition of bioavailable nitrate in many environmental systems. Dissimilatory

48 nitrate reduction is the first step for two processes in the nitrogen cycle, denitrification to $\mathrm{N}_{2}$ and

49 dissimilatory nitrate reduction to ammonium (DNRA, also referred to as nitrate ammonification)

50 (Fig. 1A). Although these processes serve different roles, both impact the isotopic composition

51 of residual nitrate in ecosystems through the nitrate reduction step. 
a.

b.

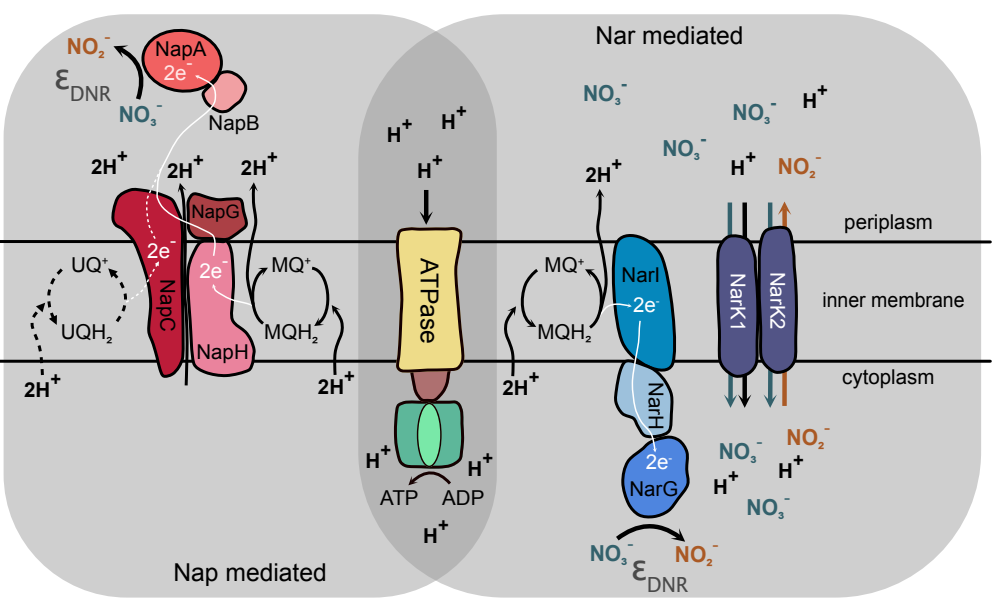

Fig. 1- (Top left) An overview of the nitrogen cycle with focus on the dissimilatory nitrate reduction step. (Right) The schematic highlights differences for how nitrate reduction is catalyzed in Nap versus Nar enzymes. Isotope fractionation $\left(\varepsilon_{\mathrm{DNR}}\right)$ occurs during the reduction of nitrate to nitrite. White lines indicate the direction of electron transfer. Black lines indicate proton translocation. In the case of Nap reductases, there are two main potential pathways for nitrate reduction to occur. Bacteria may express NapABC (dashed lines), where NapC oxidizes ubiquinol $\left(\mathrm{UQH}_{2}\right)$ to ubiquinone $\left(\mathrm{UQ}^{+}\right)$, liberating two protons and two electrons. The electrons are transferred to NapB then NapA. Alternatively, a bacterium may express NapABCGH (solid lines). Here $\mathrm{NapH}$ oxidizes menaquinol $\left(\mathrm{MQH}_{2}\right)$ to menaquinone $\left(\mathrm{MQ}^{+}\right)$and the electrons have an additional transfer step from NapG to NapC, translocating two additional protons. The Nar reductase uses NarI to oxidize $\mathrm{UQH}_{2}$ to $\mathrm{UQ}^{+}$and transfers electrons to NarH then NarG. NarK1 is a symporter that transports nitrate into the cytoplasm with a proton. NarK2 is an antiporter that 70 couples the import of nitrate to the export of nitrite.

71 The proportionality of $\mathrm{N}$ and $\mathrm{O}$ isotope fractionation $\left({ }^{18} \varepsilon /{ }^{15} \varepsilon\right)$ associated with nitrate reduction in marine ecosystems generally follows a proportionality of 0.9 to $1.0{ }^{14-19}$. In terrestrial ecosystems, observational data with coupled $\mathrm{N}$ and $\mathrm{O}$ isotope measurements is more limited (summarized in Fig. 2) but the existing data suggests that the ${ }^{18} \varepsilon /{ }^{15} \varepsilon$ proportionality covers a broader and generally lower range of values between 0.5 to $0.7^{20-26}$. To date, these systematic differences in ${ }^{18} \varepsilon /{ }^{15} \varepsilon$ proportionality are not fully understood and may indicate that we are missing a key feature about how nitrogen cycling processes create the isotopic signatures of nitrate observed in nature. Biogeochemical modelling and recent culturing work suggest that the terrestrial observations of low ${ }^{18} \varepsilon /{ }^{15} \varepsilon$ values could be the result of oxidative overprinting of the isotopic signal of nitrate reduction by a combination of nitrate producing processes such as anaerobic ammonium oxidation (annamox), nitrification, and enzymatic reversibility during

82 nitrate reduction ${ }^{8,27}$. However, an alternative hypothesis first proposed by Granger et al. (2008) 
83 suggests that differences in the ${ }^{18} \varepsilon /{ }^{15} \varepsilon$ proportionality observed in nature could actually be a

84 consequence of enzymatic differences during nitrate reduction.

85

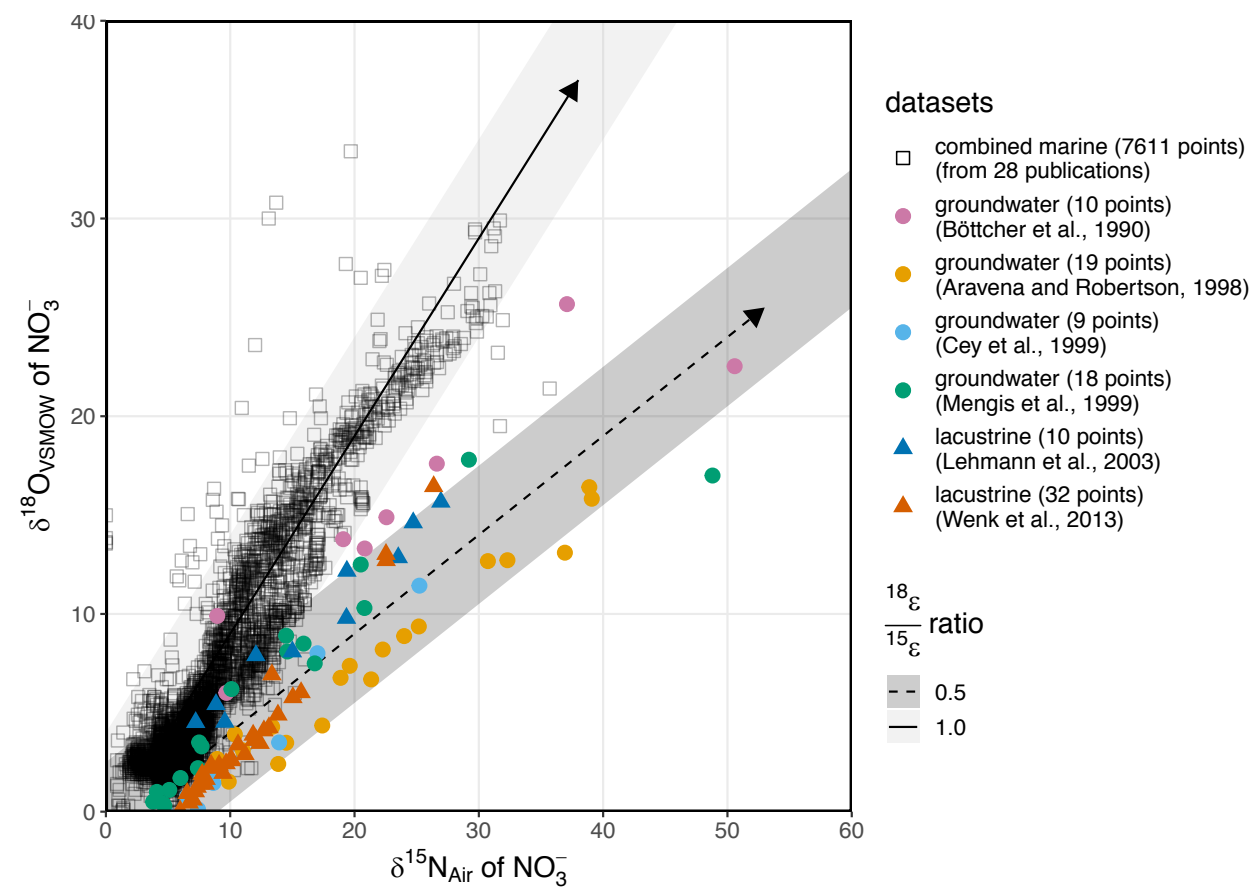

Fig. 2- A compilation of nitrate isotopic data collected from environmental samples subset into marine and terrestrial/ freshwater ecosystems. Solid lines and dashed lines indicate ${ }^{18} \varepsilon /{ }^{15} \varepsilon$ proportionalities of 1.0 and 0.5 , respectively, with gray shaded bands showing a range of possible intercepts. See SI for details on the literature data.

Dissimilatory nitrate reduction can be catalyzed by the periplasmic enzyme Nap (catalytic subunit NapA) and the membrane bound cytosolic enzyme Nar (catalytic subunit narG). Bacteria can harbor either or both of these nitrate reductases ${ }^{28-30}$ and neither is linked exclusively to either denitrification or DNRA. The few studies that have specifically examined the isotope effects of Nap reductases ${ }^{7,31,32}$ indicate that Nap $\mathrm{N}$ isotope fractionation $\left({ }^{15} \varepsilon\right)$ ranges from 11.4 $39.8 \%$, overlapping with that of Nar reductases (6.6-31.6\%o). However, the proportionality between $\mathrm{O}$ and $\mathrm{N}$ isotope fractionation appears to differ between Nap and Nar-based nitrate reduction. The purple photoheterotroph Rhodobacter sphaeroides and the chemotrophic sulfur oxidizer Sulfurimonas gotlandica both have only a Nap reductase and were examined by Granger et al. (2008); Treibergs \& Granger (2017) and Frey et al., 2014, respectively. The isotopic data from the Nap reductases in these organisms revealed ${ }^{18} \varepsilon /{ }^{15} \varepsilon$ values between $0.57-$ 0.68 for $R$. sphaeroides and $0.43-0.68$ for $S$. gotlandica, in contrast with the ${ }^{18} \varepsilon /{ }^{15} \varepsilon$ 
103 proportionality of $\sim 0.9$ in Nar based nitrate reduction ${ }^{7,32-34}$. Here, we present experimental

104 results based on six different nitrate-reducing microorganisms that encode Nar, Nap or both

105 enzymes, as well gene deletion mutants of the enzymes' catalytic subunits (NarG and NapA) to

106 test the hypothesis that differences in ${ }^{18} \varepsilon /{ }^{15} \varepsilon$ proportionality may stem solely from enzymatic

107 differences and explore the implications of our results for the environmental interpretation of

108 nitrate isotope signatures.

\section{Methods}

\section{Strains}

112 All strains cultured for this study have either the gene for the cytosolic nitrate reductase (narG),

113 the gene for the periplasmic nitrate reductase (napA), or both. The strains that have both narG

114 and napA are Pseudomonas aeruginosa PA14 (DSM 19882) and Paracoccus denitrificans

115 PD1222, a derivative of DSM $413^{35,36}$. The strains with only napA are Desulfovibrio

116 desulfuricans DSM 642 , Shewanella loihica DSM (17748) ${ }^{37-39}$, and a markerless narG deletion

117 mutant of $P$. aeruginosa PA14 ${ }^{40}$, hereafter referred to as PA14 $\triangle$ nar. The strains with only narG 118 are Bacillus vireti (DSM 15602), Bacillus bataviensis (DSM 15601) ${ }^{41}$, and a markerless napA

119 deletion mutant of P. aeruginosa PA14, hereafter referred to as PA14 $\triangle$ nap.

Culturing

122 PA14 strains were grown at $30^{\circ} \mathrm{C}$ and $37^{\circ} \mathrm{C}$ (PA14 $\triangle$ nar) in defined MOPS minimal media

123 amended with $25 \mathrm{mM}$ sodium succinate as the sole carbon source ${ }^{42}$, as well as $25 \mathrm{~g} / \mathrm{L} \mathrm{LB}$ broth.

124 B. vireti and B. bataviensis were grown at $30^{\circ} \mathrm{C}$ in $30 \mathrm{~g} / \mathrm{L}$ tryptic soy broth (TSB) amended with

$12513 \mathrm{mM}$ glucose and $11 \mathrm{mM}$ sodium succinate ${ }^{43}$. D. desulfuricans was grown at $30^{\circ} \mathrm{C}$ in Postgate's

126 defined medium ${ }^{44}$, which contains $20 \mathrm{mM}$ lactate and $1 \mathrm{~g} / \mathrm{L}$ yeast extract as carbon sources as

127 well as sodium thioglycolate $(0.1 \mathrm{~g} / \mathrm{L})$ as a reductant. S. loihica was grown at $30^{\circ} \mathrm{C}$ in a

128 phosphate buffered minimal salts medium amended with 5, 25, or 30mM sodium lactate as the

129 sole carbon source (Yoon et al. 2015). P. denitrificans was grown at $30^{\circ} \mathrm{C}$ in a defined minimal

130 salts medium amended with $25 \mathrm{mM}$ sodium acetate as the sole carbon source (Hahnke et al.

131 2014). For all nitrate reduction experiments, $\mathrm{NaNO}_{3}{ }^{-}$was injected from a concentrated stock

132 solution into each culture tube. S. loihica media was amended with approximately $10 \mathrm{mM} \mathrm{NaNO}_{3}$ 
133 in this way and all other media recipes were amended with approximately $25 \mathrm{mM} \mathrm{NaNO}_{3}$. Exact

134 concentrations in each sample were confirmed by ion chromatography.

136 For all anaerobic growth experiments, media was sparged with $\mathrm{N}_{2}$ gas and cultures were

137 incubated while shaking at $250 \mathrm{rpm}$ in balch tubes containing $20 \mathrm{~mL}$ of media and $5 \mathrm{~mL}$ of $\mathrm{N}_{2}$

138 headspace at 1.1 bar and sealed with blue butyl rubber stoppers. For aerobic growth, culture tubes

139 were incubated while shaking at 250rpm. Agar plates for reviving strains from frozen stock were

140 prepared by amending each media recipe with $15 \mathrm{~g} / \mathrm{L}$ agar. All strains except $D$. desulfuricans

141 (an obligate anaerobe) were revived on aerobic agar plates and passaged three times in liquid

142 medium before inoculating isotope fractionation experiments with $1 \%$ culture (v/v). $D$.

143 desulfuricans was inoculated directly from freezer stocks into anaerobic culture medium and

144 passaged 5 times before inoculating isotope fractionation experiments.

Isotope Fractionation Experiments

147 All strains were grown in triplicate in their respective media in the presence of nitrate and

148 sampled at regular intervals for nitrate consumption and nitrate isotopic composition. Growth

149 was monitored directly in the culture tubes by optical density (OD) using a Spectronic 20

150 spectrophotometer at a wavelength of $660 \mathrm{~nm}$ for B. vireti and B. bataviensis, and 600nm for all

151 other strains. At each time point, approximately $2 \mathrm{~mL}$ of sample was withdrawn through the

152 stopper using a 23-gauge needle attached to a syringe. Syringes were flushed with nitrogen prior

153 to sampling to preserve the anaerobic environment within the balch tubes. Samples were filter

154 sterilized with $0.2 \mu \mathrm{m}$ PES filters, aliquoted for later quantification and isotopic analysis, and

155 stored at $-20^{\circ} \mathrm{C}$. Aliquots for ion chromatography (IC) were immediately diluted in $0.1 \mathrm{M} \mathrm{NaOH}$

$156(\mathrm{pH} 11)$ to stabilize nitrite. For $P$. aeruginosa and B. vireti, the experiment was additionally

157 repeated in media made from ${ }^{18} \mathrm{O}$ enriched water (OLM-240-10-1, Cambridge Isotope

158 Laboratories, Inc.) at a final $\delta^{18} \mathrm{O}_{\text {water }}$ of approximately $+100 \%$.

Sample Analysis

161 Nitrate and nitrite concentrations were quantified using a Dionex ICS-6000 Ion Chromatograph

162 equipped with an IonPac AS11-HC column and a variable wavelength absorbance (UV/Vis)

163 detector to allow for accurate analyte detection in complex media (LB, TSB). Samples were 
eluted isocratically with $20 \mathrm{mM} \mathrm{KOH}$ at a flow rate of $1 \mathrm{~mL} /$ minute. Nitrate and nitrite peaks were measured at a wavelength of $210 \mathrm{~nm}$ and quantified against laboratory standards prepared in the same media backgrounds. The $\mathrm{N}$ and $\mathrm{O}$ isotopic composition of nitrate was determined in the

167 Sigman Lab at Princeton University using the denitrifier method ${ }^{47,48}$ with 20 nmol nitrate per

168 analysis. Nitrite removal was performed prior to isotopic analysis for all samples with nitrite concentrations $>1 \%$ nitrate using the sulfamic acid method ${ }^{49}$. The isotopic measurements were calibrated against the potassium nitrate reference standards IAEA-NO3 $\left(\delta^{15} \mathrm{~N}=4.7 \%\right.$ vs. air,

$171 \delta^{18} \mathrm{O}=25.6 \%$ vs. Vienna Standard Mean Ocean Water (VSMOW)), provided by the

172 International Atomic Energy Agency and USGS34 $\left(\delta^{15} \mathrm{~N}=-1.8 \%\right.$ vs. air, $\delta^{18} \mathrm{O}=-27.9 \%$ vs.

173 VSMOW) provided by the United States Geological Survey, each measured at two different

174 concentrations every 8 samples to correct for injection volumes. Analytical runs were corrected

175 for instrument drift based on an $\mathrm{N}_{2} \mathrm{O}$ drift monitoring standard. All isotopic data are reported in conventional delta notation versus the international reference scales for $\mathrm{N}$ (Air) and $\mathrm{O}$

177 (VSMOW): $\delta^{15} \mathrm{~N}=\left(\left[{ }^{15} \mathrm{~N} /{ }^{14} \mathrm{~N}\right]_{\text {sample }} /\left[{ }^{15} \mathrm{~N} /{ }^{14} \mathrm{~N}\right]_{\text {air }}-1\right)$ and $\delta^{18} \mathrm{O}=\left(\left[{ }^{18} \mathrm{O} /{ }^{16} \mathrm{O}\right]_{\text {sample }} /\left[{ }^{18} \mathrm{O} /{ }^{16} \mathrm{O}\right]\right.$ vsmow -

178 1). $\delta$ values reported in per mil (\%o) are implicitly multiplied by a factor of $1000{ }^{50}$. The

179 analytical precision of the nitrate monitoring standard used across all analytical runs was $0.06 \%$

180 for $\delta^{15} \mathrm{~N}$ and $0.69 \%$ for $\delta^{18} \mathrm{O}(1 \sigma, \mathrm{n}=33)$. Additionally, all fractionation experiments were run

181 using the same nitrate source in different media, thus initial time points across all experiments

182 provide an estimate of sample analytical precision: $0.07 \%$ for $\delta^{15} \mathrm{~N}$ and $0.43 \%$ for $\delta^{18} \mathrm{O}(1 \sigma$, $183 \mathrm{n}=52)$.

\section{Calculations}

186 Isotope effects: the nitrate $\delta^{15} \mathrm{~N}$ and $\delta^{18} \mathrm{O}$ measurements were fit to the following linear equations 187 to estimate the $\mathrm{N}$ and $\mathrm{O}$ isotope effects $\left({ }^{15} \varepsilon\right.$ and $\left.{ }^{18} \varepsilon\right)$ and isotope effect proportionality $\left({ }^{18} \varepsilon /{ }^{15} \varepsilon\right)$ 188 imparted on nitrate during microbial nitrate reduction from the slope of the regressions ${ }^{51}$ :

$$
\ln \left(\frac{\delta^{15} N+1}{\delta^{15} N_{\text {initial }}+1}\right)={ }^{15} \epsilon \cdot \ln (f)
$$




$$
\ln \left(\frac{\delta^{18} O+1}{\delta^{18} O_{\text {initial }}+1}\right)={ }^{18} \epsilon \cdot \ln (f)
$$

$$
\ln \left(\frac{\delta^{18} O+1}{\delta^{18} O_{\text {initial }}+1}\right)=\frac{{ }^{18} \epsilon}{{ }^{15} \epsilon} \cdot \ln \left(\frac{\delta^{15} N+1}{\delta^{15} N_{\text {initial }}+1}\right) \quad \text { Eq. } 3
$$

where $f=\left[\mathrm{NO}_{3}{ }^{-}\right] /\left[\mathrm{NO}_{3}{ }^{-}\right]_{\text {initial }}$ is the fraction of nitrate remaining and $\delta$ and $\varepsilon$ values in per mil (\%o)

are implicitly multiplied by a factor of $1000^{50}$. The errors of the regression slopes were used to estimate standard errors for ${ }^{15} \varepsilon$ (Eq. 1), ${ }^{18} \varepsilon$ (Eq. 2), and ${ }^{18} \varepsilon /{ }^{15} \varepsilon$ (Eq. 3). Note that for this implementation of the Rayleigh distillation model (Eq. 1 \& 2), normal kinetic isotope effects (reflecting higher reaction rates of the lighter isotopes) are negative $(\varepsilon<0)$ and are reported as such in Table S1. The opposite convention with normal kinetic isotope effects reported as $\varepsilon>0$ is also not uncommon and all comparisons with literature data carefully consider the convention used in each publication. For visual representation of Eq. 3 in figures, the following more intuitive but slightly less accurate linearizations were used (Eq. 4 - 6):

$$
\ln \left(\frac{\delta^{15} N+1}{\delta^{15} N_{\text {initial }}+1}\right) \approx \delta^{15} N-\delta^{15} N_{\text {initial }}=\Delta \delta^{15} N \quad \text { Eq. } 4
$$

$$
\ln \left(\frac{\delta^{18} O+1}{\delta^{18} O_{\text {initial }}+1}\right) \approx \delta^{18} O-\delta^{18} O_{\text {initial }}=\Delta \delta^{18} O \quad \text { Eq. } 5
$$

$$
\Delta \delta^{18} O=\frac{{ }^{18} \epsilon}{{ }^{15} \epsilon} \cdot \Delta \delta^{15} N
$$

209 Sequence Alignment and Gene Trees: Amino acid sequences for napA and narG reductase genes

210 (see Table S2 for details) were aligned using ClustalOmega Multiple Sequence Alignment ${ }^{52}$. A

211 list of gene accession numbers is available in SI Table 2. Maximum clade credibility gene trees

212 were constructed using MrBayes' Markov chain Monte Carlo analysis under an inverse gamma 213 rate variation model with default parameters ${ }^{53}$. 


\section{Results and Discussion}

216 Growth of cultures

217 Growth rates are recorded in SI Table 1. All growth curves and nitrate consumption data are

218 depicted in SI Figs. 1 and 2. No quantitative growth curve data was collected for S. loihica and

219 D. desulfuricans. While turbidity was detected in S. loihica, clumping prevented accurate optical

220 density measurements. D. desulfuricans was grown in Postgate's medium which precipitates iron

221 sulfides and iron hydroxides, preventing accurate optical density measurements. All strains

222 consumed nitrate successfully under fully anaerobic conditions, except for PA14 $\Delta$ nar which

223 required $\mathrm{O}_{2}$ for growth and only consumed significant quantities of nitrate while also exposed to

224 air. Nitrate consumption differed by strain and medium and ranged from as fast as $\sim 15 \mathrm{mM}$

225 nitrate in 8 hours (B. vireti) to as slow as $15 \mathrm{mM}$ nitrate in 80 hours (PA $\Delta$ nap). See Fig. S2 for

226 details.

228 Growth in strains of denitrifying bacteria that cannot perform DNRA (P. aeruginosa, $P$.

229 denitrificans) (Fig.1) had little to no nitrite accumulation. However, strains of bacteria that have

230 the potential to perform DNRA in addition to denitrification (B. vireti, B. bataviensis, D.

231 desulfuricans, S. loihica) concentrated nitrite during the experiments (SI Fig. 2). This was

232 particularly pronounced in B. vireti and B. bataviensis. Consequently, later timepoints for these

233 experiments could not be analyzed directly for their nitrate isotopic composition because the

234 sulfamic acid nitrite removal method is only effective to a 7:1 nitrite:nitrate $(\mathrm{mol} / \mathrm{mol})$ mixing

235 ratio $^{49}$. Nitrate in several of these samples with exceedingly high nitrite/ nitrate ratios was thus

236 separated from nitrite by ion chromatography coupled to fraction collection to enable isotopic

237 measurements. The analytical impact of residual nitrite from incomplete nitrite removal by

238 sulfamic acid is discussed in more detail in the SI.

240 During all time course experiments, decreases in nitrate concentration corresponded to an 241 increasingly enriched residual nitrate pool (SI Figs. 3, 4). Experimental conditions and ${ }^{18} \varepsilon /{ }^{15} \varepsilon$

242 proportionality values are summarized in Table $1 .{ }^{15} \varepsilon$ values ranged from $10.8-34.8 \%$. ${ }^{18} \varepsilon$

243 values ranged from 5.2 - 29.6\% (SI Table 1). Isotopic data fit a closed system Rayleigh model 
244 for isotope fractionation, with data largely conforming to a linear relationship of $\delta^{15} \mathrm{~N}$ or $\delta^{18} \mathrm{O}$

245 versus the natural logarithm of the remaining nitrate (SI Figs. 3, 4).

247 Table 1- Summary of isotope fractionation experiments. Tracer experiments are included as 248 replicates. Standard error calculated from all experimental replicates.

249

250

\begin{tabular}{l|c|c|c} 
Organism & $\begin{array}{c}\text { Reductase } \\
\text { Gene(s) }\end{array}$ & Medium & $\begin{array}{c}\mathbf{1 8}_{\boldsymbol{\varepsilon}} / \mathbf{1 5}_{\boldsymbol{\varepsilon}}+/- \\
\text { std. } \text { err. }\end{array}$ \\
\hline$P$. aeruginosa PA14 & both & LB & $0.97+/-0.02$ \\
$P$. aeruginosa PA14 & both & MOPS & $0.63+/-0.02$ \\
$P$. aeruginosa $\Delta$ napA & narG & LB & $0.91+/-0.01$ \\
$P$. aeruginosa $\Delta$ napA & narG & MOPS & $0.85+/-0.02$ \\
$P$. aeruginosa $\Delta$ narG & napA & LB & $0.49+/-0.00$ \\
\hline$P$. denitrificans & both & Hahnke & $0.92+/-0.01$ \\
B. bataviensis & narG & TSB & $0.61+/-0.06$ \\
B. vireti & narG & TSB & $0.64+/-0.04$ \\
$D$. desulfuricans & napA & Postgate & $0.63+/-0.06$ \\
S. loihica & napA & SL & $0.55+/-0.01$
\end{tabular}

Nitrate reductases have enzyme specific ${ }^{18} \varepsilon /{ }^{15} \varepsilon$ coupling

253 Our data indicate an enzyme specific isotope effect for the Nar and Nap reductases. The PA14

254 knock-out nitrate reduction experiments show that the Nap reductase in this organism has an ${ }^{18} \varepsilon /$

$255{ }^{15} \varepsilon$ proportionality of 0.49 while that of the Nar reductase in the same organism has a value of

$2560.86-0.91$ (Table 1, Fig. 3). The ${ }^{18} \mathrm{O}$ tracer experiments confirm that no back reaction of nitrite

257 or exchange with ambient water occurred (SI Fig. 6). The PA14 $\triangle$ nar data was substantiated by

258 the $D$. desulfuricans and $S$. loihica experiments, with ${ }^{18} \varepsilon /{ }^{15} \varepsilon$ values of $0.63+/-0.06$ and 0.55

$259+/-0.01$, respectively (Table 1; Fig. 4). Together, our data suggest ${ }^{18} \varepsilon /{ }^{15} \varepsilon$ differences can be

260 purely enzymatic, challenging the hypothesis that environmental ${ }^{18} \varepsilon /{ }^{15} \varepsilon$ patterns require nitrite

261 re-oxidation from enzymatic reversibility, nitrification or anammox ${ }^{27}$. These observations for ${ }^{18} \varepsilon$

$262 /{ }^{15} \varepsilon$ from nitrate reduction by the Nap reductase in PA14 $\Delta$ nar are similar to all other available

263 observations from organisms that naturally have only this reductase, with ${ }^{18} \varepsilon /{ }^{15} \varepsilon$ couplings of

2640.63 and 0.51 observed in $R$. sphaeroides and S. gotlandica, respectively ${ }^{7,31,32}$ (Fig. 4). 


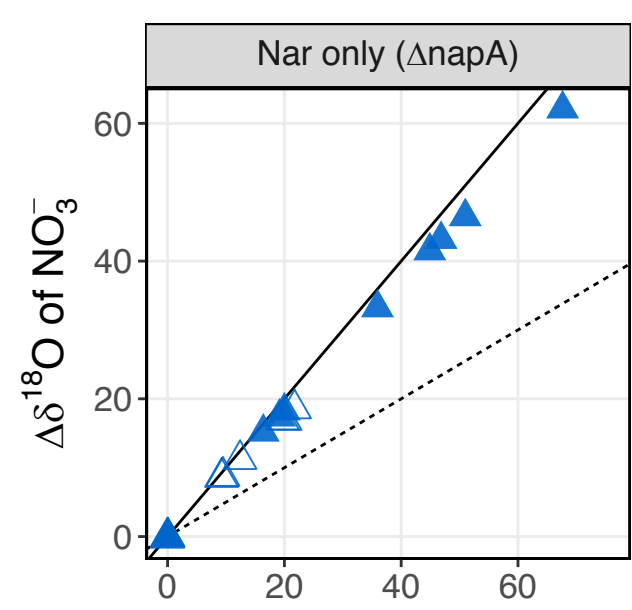

266

267

268

269

270

271

272

273

274

275

276

277

278

279

280

281

282 filled points indicate cultures grown in LB. reducing nitrate with Nar.
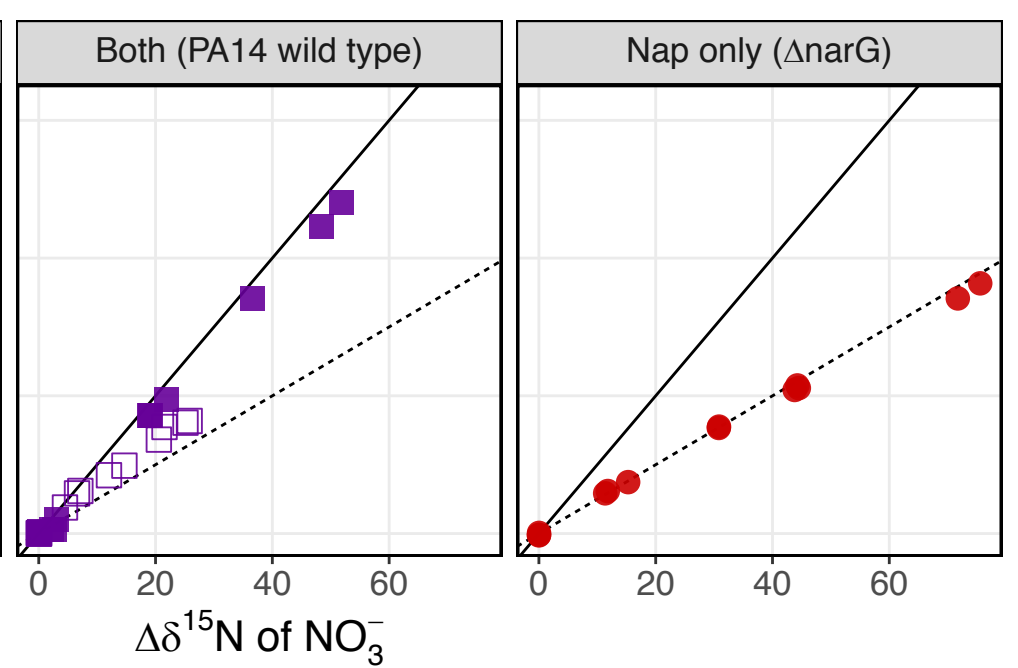

Fig. 3- The change in $\delta^{18} \mathrm{O}$ plotted versus change in $\delta^{15} \mathrm{~N}$ for the $P$. aeruginosa PA14 wild type (WT) and mutant experiments. "Nar only" corresponds to the PA14 $\Delta$ napA strain, and "Nap only" corresponds to the PA14 $\Delta$ narG strain. Solid lines and dashed lines indicate ${ }^{18} \varepsilon /{ }^{15} \varepsilon$ proportionalities of 1.0 and 0.5 , respectively. Open points indicate cultures grown in MOPS and

As discussed above, the PA14 $\triangle$ nap strain had an ${ }^{18} \varepsilon /{ }^{15} \varepsilon$ proportionality of $\sim 0.9$ which is consistent with previous reports from organisms that harbor only Nar (Fig. 4) ${ }^{7,32-34,54}$. Despite having both nitrate reductases present, $P$. denitrificans has been shown in the literature and in our own experiments to also have an ${ }^{18} \varepsilon /{ }^{15} \varepsilon$ coupling of $0.92+/-0.01{ }^{7,32,33}$ (Fig. 4). Previous research has demonstrated that $P$. denitrificans PD1222 only uses the Nap reductase under microaerobic conditions and/ or in the presence of highly reduced carbon sources ${ }^{55,56}$. The culture conditions for $P$. denitrificans used in this study (completely anaerobic conditions, relatively oxidized carbon sources) are not conducive to Nap expression based on the literature data. The ${ }^{18} \varepsilon /{ }^{15} \varepsilon$ signal we observed in our data is therefore consistent with $P$. denitrificans only 

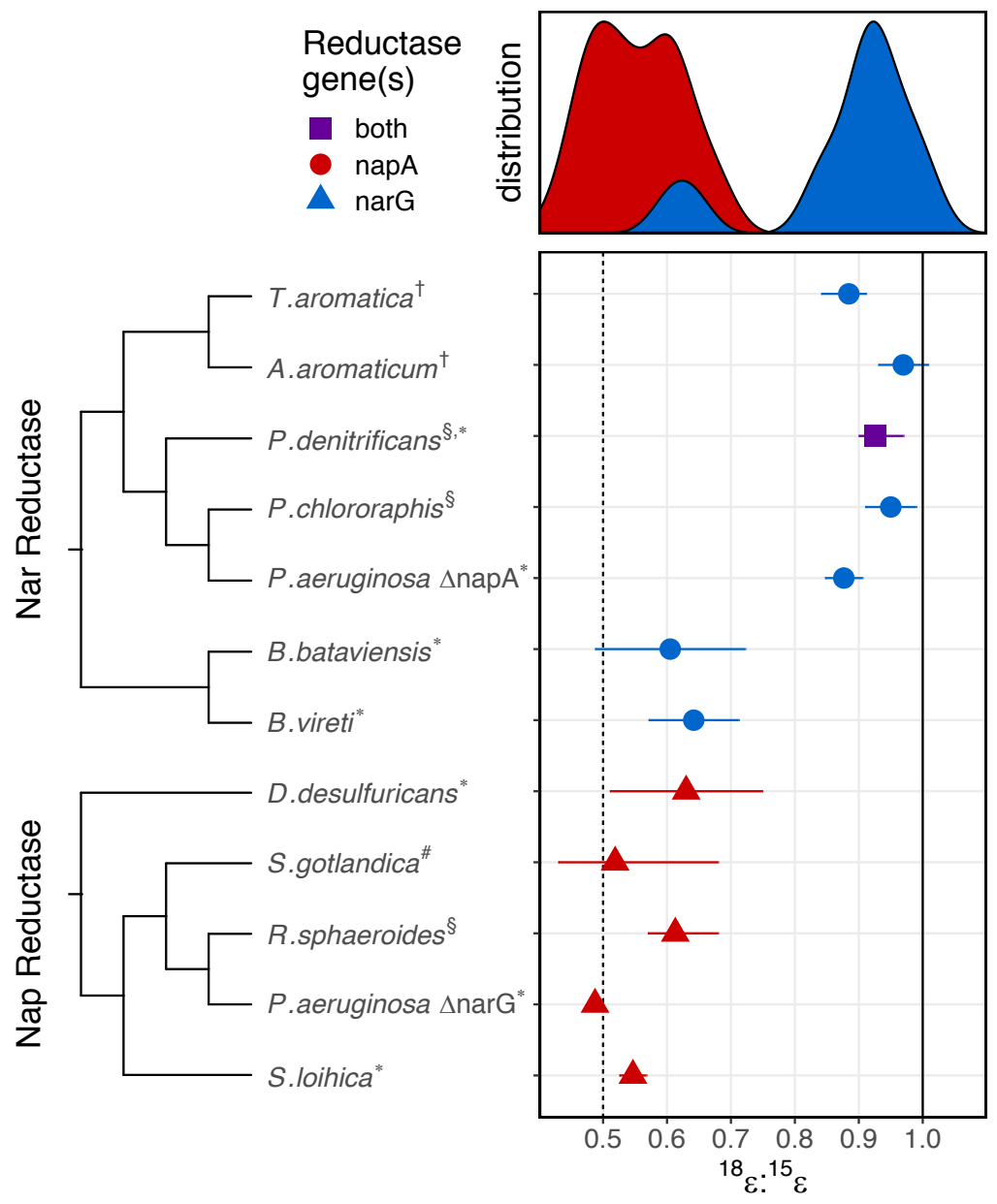

Fig. 4- Maximum clade credibility gene trees of the Nap and Nar reductases and a summary of known ${ }^{18} \varepsilon /{ }^{15} \varepsilon$ values (symbols denote averages, error bars denote value ranges if multiple values available or $+/-2$ standard errors for single values) with a distribution of these ranges shown above. Solid line and dashed line indicates ${ }^{18} \varepsilon /{ }^{15} \varepsilon$ of 1.0 and 0.5 , respectively. Colors and shapes indicate the nitrate reductase that is part of the genome of each strain (blue circles: narG only; red triangles: napA only). P. denitrificans (purple square) has both genes but under the culturing conditions employed only uses narG ${ }^{57,58}$. E. coli TMAO reductase used as an outgroup in both gene trees. Data collected in this study indicated with an asterisk (*). Literature data collected from (Frey et al., 2014 (\#); Granger et al., $2008(\S)$; Wunderlich et al., $2012(\dagger))$.

In contrast to all other data on Nar reductases, $B$. vireti and B. bataviensis have a significantly lower ${ }^{18} \varepsilon /{ }^{15} \varepsilon$ : $0.64+/-0.04$ and $0.61+/-0.06$, respectively (Table 1; Fig. 4). Although ${ }^{18} \varepsilon /{ }^{15} \varepsilon$ values between biological replicates covered a wider range than in other organisms, likely due to analytical artifacts from nitrite build-up (see SI discussion on nitrite accumulation), Bacillus ${ }^{18} \varepsilon$ / ${ }^{15} \varepsilon$ values were robustly and consistently lower than all other Nar reductases (Fig. 4). Overall, the Bacillus data indicate that it is possible for some Nar reductases to have distinct and lower ${ }^{18} \varepsilon$ 
$301 /{ }^{15} \varepsilon$ proportionality, adding to the complexity of interpreting isotopic signals of nitrate reduction

302 in ecosystems.

\section{Roles of Nap and Nar reductases}

305 The Nar reductase is known as the primary respiratory reductase amongst denitrifying bacteria.

306 The nar operon is highly conserved, with narGHI present in every known Nar-bearing denitrifier

$307{ }^{28}$. Its singular role is in providing energy conservation under anaerobic conditions where high

308 levels of nitrate are present. The Nap reductase, however, has been implicated in both aerobic

309 and traditional anaerobic denitrification, DNRA, redox balancing, nitrate scavenging, and even

310 magnetite biomineralization ${ }^{55,56,59-63}$. The nap operon is much less conserved, with several

311 combinations of the eleven different genes found across species $28,30,64,65$. The regulation of these

312 enzymes also differs. As Nar is distinctly used for respiration, the nar operon is upregulated

313 under anaerobic conditions and by the presence of nitrate. Nap regulation, however, is more

314 complicated given the variable operon conformations and assorted functions across species the

315 Nap reductase can perform. For example, reduced carbon sources can upregulate nap expression

316 in some Nap-bearing bacteria $55,56,58,66$. Additionally, the presence of either oxygen or nitrate can

317 up or down-regulate nap expression depending on species ${ }^{63,67-69}$. The gene regulation of these

318 enzymes thus ties bacterial preference of reducing nitrate with Nar versus Nap to environmental

319 constraints.

321 Bacterial preference of using the Nar or Nap reductase was exemplified in the wild type PA14

322 strain experiments when grown in different mediums. The wild type PA14 strain grown in

323 MOPS medium had an ${ }^{18} \varepsilon /{ }^{15} \varepsilon$ proportionality of $0.63+/-0.02$ (Table 1; Fig. 3 ). This is a

324 midpoint value in comparison to the ${ }^{18} \varepsilon /{ }^{15} \varepsilon$ proportionality measured in the PA14 $\triangle$ nap and

325 PA14 $\triangle$ nar strains and suggests that PA14 was using both nitrate reductases. The Nap reductase

326 for $P$. aeruginosa is used as a backup redox balancing mechanism, in particular under conditions

327 where electron acceptors are limiting ${ }^{70}$. When grown in LB, this strain exhibited a higher ${ }^{18} \varepsilon /$

$328{ }^{15} \varepsilon$ proportionality of $0.97+/-0.02$ (Table 1 ). While LB broth is considered a rich medium, it is

329 actually carbon limited, with mostly amino acids available for uptake ${ }^{71}$. This would cause lower

$330 \mathrm{C} / \mathrm{N}$ ratios in contrast to the MOPS minimal medium, in which we provide excess succinate as a 
331 carbon source. Past research in E. coli has shown that the Nar reductase has a selective advantage

332 under low carbon and high nitrate concentrations, which is the case in our LB grown cultures ${ }^{62}$.

333 Furthermore, this effect does not occur in the PA14 $\triangle$ nap strain, suggesting that this is not a

334 difference in how the Nar reductase performs in LB versus minimal medium, but a change in

335 expression pattern by PA14 to maximize energy conservation.

Mechanism for isotopic differences

338 Regardless of differences in gene regulation, the Nap and Nar reductases still catalyze the same 339 reaction and yet have different isotope effects. The active site of both reductases are similar, with 340 both containing a Mo-bis-MGD cofactor and iron sulfur cluster. ${ }^{28,72}$. One distinction is that the 341 Nar reductase's Mo center is coordinated by an aspartate residue, while the Nap reductase is

342 coordinated by a cysteine. Cysteine is a more reduced residue that may impact the redox

343 potential of the Mo center, affecting how nitrate is bound and reduced ${ }^{73-75}$. Studies indicate that

344 Nap generally has a higher affinity for nitrate than Nar ${ }^{62,76-78}$. Furthermore, the base of its

345 substrate channel is lined with positively charged amino acid residues that guides nitrate to the

346 active site ${ }^{74,79}$. In contrast, Nar has a substrate channel with negatively charged residues that

347 may impact the rate of nitrate binding overall ${ }^{80}$. Thus, it is possible that the root of isotopic

348 differences lies within the nitrate molecule's interaction with the active site of these enzymes.

Additionally, it has been proposed that nitrate binds to the catalytic site of Nap and Nar differently. For the Nar reductase, the general mechanism for nitrate binding allows nitrate to

352 bind either $\mathrm{Mo}(\mathrm{V})$ or $\mathrm{Mo}(\mathrm{IV})$, such that an internal electron transfer may be required before the 353 nitrate molecule can be reduced by $\mathrm{Nar}^{81,82}$. This is in contrast to the Nap reductase where 354 nitrate binds molybdenum only in the reduced state, Mo(IV), and reduces the nitrate immediately 35565,74 . Frey et al. (2014) suggested that this may cause a difference in isotope fractionation as the 356 Nar reductase may be subject to an intramolecular isotope effect. While the precise mechanism 357 of nitrate binding and reduction for both Nap and Nar are still uncertain, the Nap reductase's 358 high affinity for nitrate and its faster reduction mechanism may be key in understanding the 359 differences in ${ }^{18} \varepsilon /{ }^{15} \varepsilon$ proportionality. Contrary to expectations, our results for the Bacillus 360 experiments indicate that a Nap-like isotopic signature with respect to ${ }^{18} \varepsilon /{ }^{15} \varepsilon$ proportionality is 361 possible in a Nar-reductase. Future work on the structural differences between the Bacillus and 
362 other Nar reductases may hold the key to uncovering the mechanistic basis for these isotopic

363 differences.

Interpreting ${ }^{18} \varepsilon /{ }^{15} \varepsilon$ coupling in ecosystems

366 Our research shows that nitrate reduction by Nap reductases consistently produces ${ }^{18} \varepsilon /{ }^{15} \varepsilon$

367 proportionality values that are lower than those observed in marine ecosystems and may explain

368 the ${ }^{18} \varepsilon /{ }^{15} \varepsilon$ signals observed in terrestrial ecosystems. The isotopic data sets collected for the

369 terrestrial data in Fig. 2 come from a diverse set of ecosystems ranging from soils to lakes to

370 riparian zones and groundwater runoff from agriculture (see SI for details). Soils in particular

371 can have a large range of redox gradients contained within a few centimeters and experience

372 drastic changes in moisture on short time scales, impacting oxygen availability ${ }^{83}$.

373 In comparison, marine systems operate at larger scales and experience less heterogeneity over

374 short spatial and temporal scales with dissimilatory nitrate reduction occurring predominately in

375 oxygen minimum zones (OMZ) and anoxic sediments ${ }^{14-17,19}$. The nar operon has a much

376 narrower regulatory range of permissible environmental conditions than the nap operon and,

377 unlike the latter, is always inhibited by the presence of $\mathrm{O}_{2}{ }^{84-86}$, which may explain the

378 predominance of nar-based nitrate reduction in stable low oxygen systems like OMZs ${ }^{87,88}$. It is

379 thus conceivable that the Nap reductase's multiple functions are more suitable for maintaining

380 bacterial homeostasis in terrestrial aquatic ecosystems that can fluctuate significantly over short

381 spatial and temporal timescales.

383 Though this hypothesis may appear at odds with the established assumption that the Nap

384 reductase is used less commonly than the Nar reductase, limited data is available on Nap versus

385 Nar use in nature. Work by Bru et al. ${ }^{89}$ and Smith et al. ${ }^{90}$ indicate that Nap and Nar gene copy

386 numbers are roughly equivalent throughout various terrestrial and freshwater environments.

387 Further, slurry incubation experiments performed by Dong et al. ${ }^{91}$ indicated that the Nap

388 reductase was more commonly used in one of the three communities of denitrifiers surveyed.

389 While similar studies specifically targeting Nap and Nar gene abundances have not been carried

390 out in marine ecosystems, at minimum this data indicates that the Nap reductase serves an

391 important role in nitrate reduction for bacteria and that its expression is comparable to Nar in

392 freshwater and terrestrial ecosystems. 
394 Since the Nap reductase is not embedded in the cytosolic membrane, and thus not directly 395 involved in proton motive force (PMF) generation, it is frequently presumed to be rarely used for 396 respiration. This explains the common assumption that the isotopic signal of nitrate reduction in 397 ecosystems must stem mainly from the membrane bound cytosolic Nar reductase, as PMF 398 generation is essential for survival and growth $7,14,17,32,33$. However, the potential to perform

399 nitrate reduction with only a Nap reductase appears to be common place, and with the right 400 auxiliary genes present in the nap operon, can be just as efficient as the Nar reductase at 401 producing a proton motive force (PMF) (Fig. 1B) ${ }^{59,65,92}$. Future work combining isotopic 402 measurements with quantification of gene expression patterns of the Nap and Nar reductases in 403 different environments can connect our culture-based results back to the trends originally 404 observed in nature. This will be critical when considering the potential impact and extent of 405 Bacillus-like Nar enzymes in nature that may have lower ${ }^{18} \varepsilon /{ }^{15} \varepsilon$ values. The regulation patterns 406 observed in the PA14 wild type strain in MOPS versus LB medium also emphasize the 407 importance of performing transcriptomics over metagenomics, as bacteria with both reductases 408 may switch between Nap and Nar depending on environmental constraints. This is particularly 409 important when considering processes such as DNRA which can use either NapA or NarG to 410 reduce nitrate. Though the Nap reductase is often implicated as the main reductase used during 411 DNRA, many species of bacteria appear to catalyze DNRA solely via the Nar reductase ${ }^{43,93-95}$.

412 The data presented in this study provides a clear indication that even closely related enzymes can

413 have very distinct isotopic signatures that may allow more comprehensive interpretations of 414 environmental data in the future. Acknowledgements

417 This research was supported by the Department of Geological Sciences at the University of 418 Colorado Boulder and a NASA Exobiology grant (80NSSC17K0667) to SHK. We would like to 419 thank Daniel Sigman for support and access to analytical instrumentation at Princeton 420 University. We are grateful to Emma Kast, Dario Marconi, Sergey Oleynik and other members 421 of the Sigman Lab for providing guidance and support throughout sample processing and 422 isotopic analysis. We also sincerely thank the Dietrich Lab for providing us with the $P$. 423 aeruginosa mutant strains. 


\section{References}

(1) Gruber, N.; Galloway, J. N. An Earth-System Perspective of the Global Nitrogen Cycle. Nature 2008, 451 (7176), 293-296. https://doi.org/10.1038/nature06592.

(2) Haber, F. The Synthesis of Ammonia from Its Elements, Nobel Lecture. Resonance 1920, 7 (9), 86-94. https://doi.org/10.1007/BF02836189.

(3) Simon, J.; Klotz, M. G. Diversity and Evolution of Bioenergetic Systems Involved in Microbial Nitrogen Compound Transformations. Biochim. Biophys. Acta BBA - Bioenerg. 2013, 1827 (2), 114-135. https://doi.org/10.1016/j.bbabio.2012.07.005.

(4) Brunner, B.; Contreras, S.; Lehmann, M. F.; Matantseva, O.; Rollog, M.; Kalvelage, T.; Klockgether, G.; Lavik, G.; Jetten, M. S. M.; Kartal, B.; Kuypers, M. M. M. Nitrogen Isotope Effects Induced by Anammox Bacteria. Proc. Natl. Acad. Sci. 2013, 110 (47), 18994-18999. https://doi.org/10.1073/pnas.1310488110.

(5) Buchwald, C.; Casciotti, K. L. Oxygen Isotopic Fractionation and Exchange during Bacterial Nitrite Oxidation. Limnol. Oceanogr. 2010, 55 (3), 1064-1074. https://doi.org/10.4319/lo.2010.55.3.1064.

(6) Casciotti, K. L. Inverse Kinetic Isotope Fractionation during Bacterial Nitrite Oxidation. Geochim. Cosmochim. Acta 2009, 73 (7), 2061-2076. https://doi.org/10.1016/j.gca.2008.12.022.

(7) Granger, J.; Sigman, D. M.; Lehmann, M. F.; Tortell, P. D. Nitrogen and Oxygen Isotope Fractionation during Dissimilatory Nitrate Reduction by Denitrifying Bacteria. Limnol. Oceanogr. 2008, 53 (6), 2533-2545. https://doi.org/10.4319/lo.2008.53.6.2533.

(8) Kobayashi, K.; Makabe, A.; Yano, M.; Oshiki, M.; Kindaichi, T.; Casciotti, K. L.; Okabe, S. Dual Nitrogen and Oxygen Isotope Fractionation during Anaerobic Ammonium Oxidation by Anammox Bacteria. ISME J. 2019, 13 (10), 2426-2436. https://doi.org/10.1038/s41396-019-0440-X.

(9) Zhang, X.; Sigman, D. M.; Morel, F. M. M.; Kraepiel, A. M. L. Nitrogen Isotope Fractionation by Alternative Nitrogenases and Past Ocean Anoxia. Proc. Natl. Acad. Sci. 2014, 111 (13), 4782-4787. https://doi.org/10.1073/pnas.1402976111.

(10) Bauersachs, T.; Schouten, S.; Compaoré, J.; Wollenzien, U.; Stal, L. J.; Sinninghe Damsteé, J. S. Nitrogen Isotopic Fractionation Associated with Growth on Dinitrogen Gas and Nitrate by Cyanobacteria. Limnol. Oceanogr. 2009, 54 (4), 1403-1411.

(11) Carpenter, E. J.; Harvey, H. R.; Fry, B.; Capone, D. G. Biogeochemical Tracers of the Marine Cyanobacterium Trichodesmium. Deep Sea Res. Part Oceanogr. Res. Pap. 1997, 44 (1), 27-38.

(12) Macko, S. A.; Fogel, M. L.; Hare, P. E.; Hoering, T. C. Isotopic Fractionation of Nitrogen and Carbon in the Synthesis of Amino Acids by Microorganisms. Chem Geol 1987, 65 (1), 79-92.

(13) Minagawa, M.; Wada, E. Nitrogen Isotope Ratios of Red Tide Organisms in the East China Sea: A Characterization of Biological Nitrogen Fixation. Mar. Chem. 1986, 19 (3), 245-259.

(14) Bourbonnais, A.; Letscher, R. T.; Bange, H. W.; Échevin, V.; Larkum, J.; Mohn, J.; Yoshida, N.; Altabet, M. A. $\mathrm{N}_{2}$ O Production and Consumption from Stable Isotopic and Concentration Data in the Peruvian Coastal Upwelling System: $\mathrm{N}_{2} \mathrm{O}$ Production and Consumption off Peru. Glob. Biogeochem. Cycles 2017, 31 (4), 678-698. https://doi.org/10.1002/2016GB005567. 
(15) Casciotti, K. L.; Buchwald, C.; McIlvin, M. Implications of Nitrate and Nitrite Isotopic Measurements for the Mechanisms of Nitrogen Cycling in the Peru Oxygen Deficient Zone. Deep Sea Res. Part Oceanogr. Res. Pap. 2013, 80, 78-93.

(16) Casciotti, K. L.; McIlvin, M. R. Isotopic Analyses of Nitrate and Nitrite from Reference Mixtures and Application to Eastern Tropical North Pacific Waters. Mar. Chem. 2007, 107 (2), 184-201. https://doi.org/10.1016/j.marchem.2007.06.021.

(17) DiFiore, P. J.; Sigman, D. M.; Dunbar, R. B. Upper Ocean Nitrogen Fluxes in the Polar Antarctic Zone: Constraints from the Nitrogen and Oxygen Isotopes of Nitrate: POLAR ANTARCTIC NITRATE N AND O ISOTOPES. Geochem. Geophys. Geosystems 2009, 10 (11), n/a-n/a. https://doi.org/10.1029/2009GC002468.

(18) Gaye, B.; Nagel, B.; Dähnke, K.; Rixen, T.; Emeis, K.-C. Evidence of Parallel Denitrification and Nitrite Oxidation in the ODZ of the Arabian Sea from Paired Stable Isotopes of Nitrate and Nitrite. Glob. Biogeochem. Cycles 2013, 27 (4), 1059-1071. https://doi.org/10.1002/2011GB004115.

(19) Rafter, P. A.; DiFiore, P. J.; Sigman, D. M. Coupled Nitrate Nitrogen and Oxygen Isotopes and Organic Matter Remineralization in the Southern and Pacific Oceans: Nitrate Isotopes and Remineralization. J. Geophys. Res. Oceans 2013, 118 (10), 4781-4794. https://doi.org/10.1002/jgrc.20316.

(20) Aravena, R.; Robertson, W. D. Use of Multiple Isotope Tracers to Evaluate Denitrification in Ground Water: Study of Nitrate from a Large-Flux Septic System Plume. Ground Water 1998, 36 (6), 975-982.

(21) Böttcher, J.; Strebel, O.; Voerkelius, S.; Schmidt, H.-L. Using Isotope Fractionation of Nitrate-Nitrogen and Nitrate-Oxygen for Evaluation of Microbial Denitrification in a Sandy Aquifer. J. Hydrol. 1990, 114 (3-4), 413-424. https://doi.org/10.1016/00221694(90)90068-9.

(22) Houlton, B. Z.; Sigman, D. M.; Hedin, L. O. Isotopic Evidence for Large Gaseous Nitrogen Losses from Tropical Rainforests. Proc. Natl. Acad. Sci. 2006, 103 (23), 87458750. https://doi.org/10.1073/pnas.0510185103.

(23) Mengis, M.; Schiff, S. L.; Harris, M.; English, M. C.; Aravena, R.; Elgood, R. J.; MacLean, A. Multiple Geochemical and Isotopic Approaches for Assessing Ground Water NO3- Elimination in a Riparian Zone. Ground Water 1999, 37 (3), 448-457.

(24) Wenk, C. B.; Zopfi, J.; Blees, J.; Veronesi, M.; Niemann, H.; Lehmann, M. F. Community $\mathrm{N}$ and $\mathrm{O}$ Isotope Fractionation by Sulfide-Dependent Denitrification and Anammox in a Stratified Lacustrine Water Column. Geochim. Cosmochim. Acta 2014, 125, 551-563. https://doi.org/10.1016/j.gca.2013.10.034.

(25) Lehmann, M. F.; Reichert, P.; Bernasconi, S. M.; Barbieri, A.; McKenzie, J. A. Modelling Nitrogen and Oxygen Isotope Fractionation during Denitrification in a Lacustrine RedoxTransition Zone. Geochim. Cosmochim. Acta 2003, 67 (14), 2529-2542. https://doi.org/10.1016/S0016-7037(03)00085-1.

(26) Cey, E. E.; Rudolph, D. L.; Aravena, R.; Parkin, G. Role of the Riparian Zone in Controlling the Distribution and Fate of Agricultural Nitrogen near a Small Stream in Southern Ontario. J. Contam. Hydrol. 1999, 37 (1-2), 45-67.

(27) Granger, J.; Wankel, S. D. Isotopic Overprinting of Nitrification on Denitrification as a Ubiquitous and Unifying Feature of Environmental Nitrogen Cycling. Proc. Natl. Acad. Sci. 2016, 113 (42), E6391-E6400. https://doi.org/10.1073/pnas.1601383113. 
(28) González, P. J.; Correia, C.; Moura, I.; Brondino, C. D.; Moura, J. J. G. Bacterial Nitrate Reductases: Molecular and Biological Aspects of Nitrate Reduction. J. Inorg. Biochem. 2006, 100 (5-6), 1015-1023. https://doi.org/10.1016/j.jinorgbio.2005.11.024.

(29) Philippot, L. Denitrifying Genes in Bacterial and Archaeal Genomes. Biochim. Biophys. Acta BBA - Gene Struct. Expr. 2002, 1577 (3), 355-376. https://doi.org/10.1016/S01674781(02)00420-7.

(30) Richardson, D. J.; Berks, B. C.; Russell, D. A.; Spiro, S.; Taylor, C. J. Functional, Biochemical and Genetic Diversity of Prokaryotic Nitrate Reductases: Cell. Mol. Life Sci. 2001, 58 (2), 165-178. https://doi.org/10.1007/PL00000845.

(31) Frey, C.; Hietanen, S.; Jürgens, K.; Labrenz, M.; Voss, M. N and O Isotope Fractionation in Nitrate during Chemolithoautotrophic Denitrification by Sulfurimonas Gotlandica. Environ. Sci. Technol. 2014, 48 (22), 13229-13237. https://doi.org/10.1021/es503456g.

(32) Treibergs, L. A.; Granger, J. Enzyme Level N and O Isotope Effects of Assimilatory and Dissimilatory Nitrate Reduction. Limnol. Oceanogr. 2017, 62 (1), 272-288. https://doi.org/10.1002/lno.10393.

(33) Kritee, K.; Sigman, D. M.; Granger, J.; Ward, B. B.; Jayakumar, A.; Deutsch, C. Reduced Isotope Fractionation by Denitrification under Conditions Relevant to the Ocean. Geochim. Cosmochim. Acta 2012, 92, 243-259. https://doi.org/10.1016/j.gca.2012.05.020.

(34) Wunderlich, A.; Meckenstock, R.; Einsiedl, F. Effect of Different Carbon Substrates on Nitrate Stable Isotope Fractionation During Microbial Denitrification. Environ. Sci. Technol. 2012, 46 (9), 4861-4868. https://doi.org/10.1021/es204075b.

(35) Rahme, L.; Stevens, E.; Wolfort, S.; Shao, J.; Tompkins, R.; Ausubel, F. Common Virulence Factors for Bacterial Pathogenicity in Plants and Animals. Science 1995, 268 (5219), 1899-1902. https://doi.org/10.1126/science.7604262.

(36) Rainey, F. A.; Stakebrandt, E.; BrghardtA, J. A Re-Evaluation of the Taxonomy of Paracoccus Denitrificans and a Proposal for the Combination Paracoccus Pantotrophus Comb. Nov. Int. J. Syst. Bacteriol. 1999, 49 (2), 645-651.

(37) Beijerinck, M. W. Über Spirillum Desulfuricans Als Ursache von Sulfatreduktion. Zentralblatt Bakteriol 1895, 1, 1-9.

(38) Gao, H. Shewanella Loihica Sp. Nov., Isolated from Iron-Rich Microbial Mats in the Pacific Ocean. Int. J. Syst. Evol. Microbiol. 2006, 56 (8), 1911-1916. https://doi.org/10.1099/ijs.0.64354-0.

(39) Kluyver, A. J.; Bernardus Van Niel, C. Prospects for a Natural System of Classification of Bacteria. Zentralblatt Bakteriol. Parasitenkd. Infekt. Hyg. 1936, 94, 369-403.

(40) Dietrich, L. E. P.; Okegbe, C.; Price-Whelan, A.; Sakhtah, H.; Hunter, R. C.; Newman, D. K. Bacterial Community Morphogenesis Is Intimately Linked to the Intracellular Redox State. J. Bacteriol. 2013, 195 (7), 1371-1380. https://doi.org/10.1128/JB.02273-12.

(41) Heyrman, J.; Vanparys, B.; Logan, N. A.; Balcaen, A.; Rodríguez-Díaz, M.; Felske, A.; De Vos, P. Bacillus Novalis Sp. Nov., Bacillus Vireti Sp. Nov., Bacillus Soli Sp. Nov., Bacillus Bataviensis Sp. Nov. and Bacillus Drentensis Sp. Nov., from the Drentse A Grasslands. Int. J. Syst. Evol. Microbiol. 2004, 54 (1), 47-57. https://doi.org/10.1099/ijs.0.02723-0.

(42) Neidhardt, F. C.; Bloch, P. L.; Smith, D. F. Culture Medium for Enterobacteria. J. Bacteriol. 1974, 119 (3), 736-747. https://doi.org/10.1128/JB.119.3.736-747.1974.

(43) Mania, D.; Heylen, K.; van Spanning, R. J. M.; Frostegård, Å. The Nitrate-Ammonifying and NosZ -Carrying Bacterium B Acillus Vireti Is a Potent Source and Sink for Nitric and 
Nitrous Oxide under High Nitrate Conditions: Bacillus Vireti Is a Source and Sink for NO and $\mathrm{N}_{2}$ O. Environ. Microbiol. 2014, 16 (10), 3196-3210. https://doi.org/10.1111/14622920.12478.

(44) Postgate, J. R. Versatile Medium for the Enumeration of Sulfate-Reducing Bacteria. Appl. Microbiol. 1963, 11 (3), 265-267. https://doi.org/10.1128/AEM.11.3.265-267.1963.

(45) Yoon, S.; Cruz-García, C.; Sanford, R.; Ritalahti, K. M.; Löffler, F. E. Denitrification versus Respiratory Ammonification: Environmental Controls of Two Competing Dissimilatory NO3-/NO2- Reduction Pathways in Shewanella Loihica Strain PV-4. ISME J. 2015, 9 (5), 1093-1104. https://doi.org/10.1038/ismej.2014.201.

(46) Hahnke, S. M.; Moosmann, P.; Erb, T. J.; Strous, M. An Improved Medium for the Anaerobic Growth of Paracoccus Denitrificans Pd1222. Front. Microbiol. 2014, 5. https://doi.org/10.3389/fmicb.2014.00018.

(47) Sigman, D. M.; Casciotti, K. L.; Andreani, M.; Barford, C.; Galanter, M.; Böhlke, J. K. A Bacterial Method for the Nitrogen Isotopic Analysis of Nitrate in Seawater and Freshwater. Anal. Chem. 2001, 73 (17), 4145-4153. https://doi.org/10.1021/ac010088e.

(48) Weigand, M. A.; Foriel, J.; Barnett, B.; Oleynik, S.; Sigman, D. M. Updates to Instrumentation and Protocols for Isotopic Analysis of Nitrate by the Denitrifier Method: Denitrifier Method Protocols and Instrumentation Updates. Rapid Commun. Mass Spectrom. 2016, 30 (12), 1365-1383. https://doi.org/10.1002/rcm.7570.

(49) Granger, J.; Sigman, D. M. Removal of Nitrite with Sulfamic Acid for Nitrate N and O Isotope Analysis with the Denitrifier Method. Rapid Commun. Mass Spectrom. 2009, 23 (23), 3753-3762. https://doi.org/10.1002/rcm.4307.

(50) Coplen, T. B. Guidelines and Recommended Terms for Expression of Stable-IsotopeRatio and Gas-Ratio Measurement Results: Guidelines and Recommended Terms for Expressing Stable Isotope Results. Rapid Commun. Mass Spectrom. 2011, 25 (17), 25382560. https://doi.org/10.1002/rcm.5129.

(51) Mariotti, A.; Germon, J. C.; Hubert, P.; Kaiser, P.; Letolle, R.; Tardieux, A.; Tardieux, P. Experimental Determination of Nitrogen Kinetic Isotope Fractionation: Some Principles; Illustration for the Denitrification and Nitrification Processes. Plant Soil 1981, 62 (3), 413-430. https://doi.org/10.1007/BF02374138.

(52) Sievers, F.; Wilm, A.; Dineen, D.; Gibson, T. J.; Karplus, K.; Li, W.; Lopez, R.; McWilliam, H.; Remmert, M.; Söding, J.; Thompson, J. D.; Higgins, D. G. Fast, Scalable Generation of High-Quality Protein Multiple Sequence Alignments Using Clustal Omega. Mol. Syst. Biol. 2011, 7.

(53) Huelsenbeck, J. P.; Ronquist, F. MRBAYES: Bayesian Inference of Phylogenetic Trees. Bioinformatics 2001, 17 (8), 754-755. https://doi.org/10.1093/bioinformatics/17.8.754.

(54) Carlisle, E.; Yarnes, C.; Toney, M. D.; Bloom, A. J. Nitrate Reductase 15N Discrimination in Arabidopsis Thaliana, Zea Mays, Aspergillus Niger, Pichea Angusta, and Escherichia Coli. Front. Plant Sci. 2014, 5. https://doi.org/10.3389/fpls.2014.00317.

(55) Ellington, M. J. K.; Bhakoo, K. K.; Sawers, G.; Richardson, D. J.; Ferguson, S. J. Hierarchy of Carbon Source Selection in Paracoccus Pantotrophus: Strict Correlation between Reduction State of the Carbon Substrate and Aerobic Expression of the Nap Operon. J. Bacteriol. 2002, 184 (17), 4767-4774. https://doi.org/10.1128/JB.184.17.47674774.2002.

(56) Sears, H. J.; Sawers, G.; Berks, B. C.; Ferguson, S. J.; Richardson, D. J. Control of Periplasmic Nitrate Reductase Gene Expression (NapEDABC) from Paracoccus 
Pantotrophus in Response to Oxygen and Carbon Substrates. Microbiology 2000, 146 (11), 2977-2985. https://doi.org/10.1099/00221287-146-11-2977.

(57) Sears, H. J.; Spiro, S.; Richardson, D. J. Effect of Carbon Substrate and Aeration on Nitrate Reduction and Expression of the Periplasmic and Membrane-Bound Nitrate Reductases in Carbon-Limited Continuous Cultures of Paracoccus Denitrificans Pd1222. Microbiology 1997, 143, 3767-3774.

(58) Sears, H. J.; Ferguson, S. J.; Richardson, D. J.; Spiro, S. The Identification of a Periplasmic Nitrate Reductase in Paracoccus Denitrificans. FEMS Microbiol. Lett. 1993, 113 (1), 107-111. https://doi.org/10.1111/j.1574-6968.1993.tb06496.x.

(59) Bedzyk, L.; Wang, T.; Ye, R. W. The Periplasmic Nitrate Reductase InPseudomonas Sp. Strain G-179 Catalyzes the First Step of Denitrification. J. Bacteriol. 1999, 181 (9), 2802 2806. https://doi.org/10.1128/JB.181.9.2802-2806.1999.

(60) Ji, B.; Yang, K.; Zhu, L.; Jiang, Y.; Wang, H.; Zhou, J.; Zhang, H. Aerobic Denitrification: A Review of Important Advances of the Last 30 Years. Biotechnol. Bioprocess Eng. 2015, 20 (4), 643-651. https://doi.org/10.1007/s12257-015-0009-0.

(61) Li, Y.; Katzmann, E.; Borg, S.; Schüler, D. The Periplasmic Nitrate Reductase Nap Is Required for Anaerobic Growth and Involved in Redox Control of Magnetite Biomineralization in Magnetospirillum Gryphiswaldense. J. Bacteriol. 2012, 194 (18), 4847-4856. https://doi.org/10.1128/JB.00903-12.

(62) Potter, L. C.; Millington, P.; Griffiths, L.; Thomas, G. H.; Cole, J. A. Competition between Escherichia Coli Strains Expressing Either a Periplasmic or a Membrane-Bound Nitrate Reductase : Does Nap Confer a Selective Advantage during Nitrate-Limited Growth? Int. J. Syst. Bacteriol. 1999, 344 (1), 77-84.

(63) Stewart, V.; Lu, Y.; Darwin, A. J. Periplasmic Nitrate Reductase (NapABC Enzyme) Supports Anaerobic Respiration by Escherichia Coli K-12. J. Bacteriol. 2002, 184 (5), 1314-1323. https://doi.org/10.1128/JB.184.5.1314-1323.2002.

(64) Kraft, B.; Strous, M.; Tegetmeyer, H. E. Microbial Nitrate Respiration - Genes, Enzymes and Environmental Distribution. J. Biotechnol. 2011, 155 (1), 104-117. https://doi.org/10.1016/j.jbiotec.2010.12.025.

(65) Sparacino-Watkins, C.; Stolz, J. F.; Basu, P. Nitrate and Periplasmic Nitrate Reductases. Chem Soc Rev 2014, 43 (2), 676-706. https://doi.org/10.1039/C3CS60249D.

(66) Dong, Y.; Wang, J.; Fu, H.; Zhou, G.; Shi, M.; Gao, H. A Crp-Dependent TwoComponent System Regulates Nitrate and Nitrite Respiration in Shewanella Oneidensis. PLoS ONE 2012, 7 (12), e51643. https://doi.org/10.1371/journal.pone.0051643.

(67) Mesa, S.; Hauser, F.; Friberg, M.; Malaguti, E.; Fischer, H.-M.; Hennecke, H. Comprehensive Assessment of the Regulons Controlled by the FixLJ-FixK2-FixK1 Cascade in Bradyrhizobium Japonicum. J. Bacteriol. 2008, 190 (20), 6568-6579. https://doi.org/10.1128/JB.00748-08.

(68) Robles, E. F.; Sánchez, C.; Bonnard, N.; Delgado, M. J.; Bedmar, E. J. The Bradyrhizobium Japonicum NapEDABC Genes Are Controlled by the FixLJ-FixK2-NnrR Regulatory Cascade. Biochem. Soc. Trans. 2006, 34 (1), 108-110. https://doi.org/10.1042/BST0340108.

(69) Stewart, V. Regulation of Nitrate and Nitrite Reductase Synthesis in Enterobacteria. Antonie Van Leeuwenhoek 1994, 66 (1-3), 37-45. https://doi.org/10.1007/BF00871631.

(70) Lin, Y.-C.; Sekedat, M. D.; Cornell, W. C.; Silva, G. M.; Okegbe, C.; Price-Whelan, A.; Vogel, C.; Dietrich, L. E. P. Phenazines Regulate Nap-Dependent Denitrification in 
Pseudomonas Aeruginosa Biofilms. J. Bacteriol. 2018, 200 (9), e00031-18, /jb/200/9/e00031-18.atom. https://doi.org/10.1128/JB.00031-18.

(71) Sezonov, G.; Joseleau-Petit, D.; D’Ari, R. Escherichia Coli Physiology in Luria-Bertani Broth. J. Bacteriol. 2007, 189 (23), 8746-8749. https://doi.org/10.1128/JB.01368-07.

(72) Morozkina, E. V.; Zvyagilskaya, R. A. Nitrate Reductases: Structure, Functions, and Effect of Stress Factors. Biochem. Mosc. 2007, 72 (10), 1151-1160. https://doi.org/10.1134/S0006297907100124.

(73) Barford, D. The Role of Cysteine Residues as Redox-Sensitive Regulatory Switches. Curr. Opin. Struct. Biol. 2004, 14 (6), 679-686. https://doi.org/10.1016/j.sbi.2004.09.012.

(74) Coelho, C.; Romão, M. J. Structural and Mechanistic Insights on Nitrate Reductases. Protein Sci. 2015, 24 (12), 1901-1911. https://doi.org/10.1002/pro.2801.

(75) Wirtz, M.; Droux, M. Synthesis of the Sulfur Amino Acids: Cysteine and Methionine. Photosynth. Res. 2005, 86 (3), 345-362. https://doi.org/10.1007/s11120-005-8810-9.

(76) Arnoux, P.; Sabaty, M.; Alric, J.; Frangioni, B.; Guigliarelli, B.; Adriano, J.-M.; Pignol, D. Structural and Redox Plasticity in the Heterodimeric Periplasmic Nitrate Reductase. Nat. Struct. Mol. Biol. 2003, 10 (11), 928-934. https://doi.org/10.1038/nsb994.

(77) Gates, A. J.; Richardson, D. J.; Butt, J. N. Voltammetric Characterization of the Aerobic Energy-Dissipating Nitrate Reductase of Paracoccus Pantotrophus: Exploring the Activity of a Redox-Balancing Enzyme as a Function of Electrochemical Potential. Biochem. J. 2008, 409 (1), 159-168. https://doi.org/10.1042/BJ20071088.

(78) Pinho, D.; Besson, S.; Silva, P. J.; de Castro, B.; Moura, I. Isolation and Spectroscopic Characterization of the Membrane-Bound Nitrate Reductase from Pseudomonas Chlororaphis DSM 50135. Biochim. Biophys. Acta BBA - Gen. Subj. 2005, 1723 (1-3), 151-162. https://doi.org/10.1016/j.bbagen.2005.02.008.

(79) Najmudin, S.; González, P. J.; Trincão, J.; Coelho, C.; Mukhopadhyay, A.; Cerqueira, N. M. F. S. A.; Romão, C. C.; Moura, I.; Moura, J. J. G.; Brondino, C. D.; Romão, M. J. Periplasmic Nitrate Reductase Revisited: A Sulfur Atom Completes the Sixth Coordination of the Catalytic Molybdenum. JBIC J. Biol. Inorg. Chem. 2008, 13 (5), $737-$ 753. https://doi.org/10.1007/s00775-008-0359-6.

(80) Jormakka, M.; Richardson, D.; Byrne, B.; Iwata, S. Architecture of NarGH Reveals a Structural Classification of Mo-BisMGD Enzymes. Structure 2004, 12 (1), 95-104. https://doi.org/10.1016/j.str.2003.11.020.

(81) Anderson, L. J.; Richardson, D. J.; Butt, J. N. Catalytic Protein Film Voltammetry from a Respiratory Nitrate Reductase Provides Evidence for Complex Electrochemical Modulation of Enzyme Activity ${ }^{\dagger}$. Biochemistry 2001, 40 (38), 11294-11307. https://doi.org/10.1021/bi002706b.

(82) Marangon, J.; Paes de Sousa, P. M.; Moura, I.; Brondino, C. D.; Moura, J. J. G.; González, P. J. Substrate-Dependent Modulation of the Enzymatic Catalytic Activity: Reduction of Nitrate, Chlorate and Perchlorate by Respiratory Nitrate Reductase from Marinobacter Hydrocarbonoclasticus 617. Biochim. Biophys. Acta BBA - Bioenerg. 2012, 1817 (7), 1072-1082. https://doi.org/10.1016/j.bbabio.2012.04.011.

(83) Husson, O. Redox Potential (Eh) and PH as Drivers of Soil/Plant/Microorganism Systems: A Transdisciplinary Overview Pointing to Integrative Opportunities for Agronomy. Plant Soil 2013, 362 (1-2), 389-417. https://doi.org/10.1007/s11104-012-1429-7.

(84) Spiro, S.; Guest, J. R. FNR and Its Role in Oxygen-Regulated Gene Expression in Escherichia Coli. FEMS Microbiol. Rev. 1990, 6 (4), 399-428. 
(85) Moir, J. W. B.; Wood, N. J. Nitrate and Nitrite Transport in Bacteria: Cell. Mol. Life Sci. 2001, 58 (2), 215-224. https://doi.org/10.1007/PL00000849.

(86) Wood, N. J.; Alizadeh, T.; Bennett, S.; Pearce, J.; Ferguson, S. J.; Richardson, D. J.; Moir, J. W. B. Maximal Expression of Membrane-Bound Nitrate Reductase in Paracoccus Is Induced by Nitrate via a Third FNR-Like Regulator Named NarR. J. Bacteriol. 2001, 183 (12), 3606-3613. https://doi.org/10.1128/JB.183.12.3606-3613.2001.

(87) Lam, P.; Kuypers, M. M. M. Microbial Nitrogen Cycling Processes in Oxygen Minimum Zones. Annu. Rev. Mar. Sci. 2011, 3 (1), 317-345. https://doi.org/10.1146/annurevmarine-120709-142814.

(88) Ulloa, O.; Canfield, D. E.; DeLong, E. F.; Letelier, R. M.; Stewart, F. J. Microbial Oceanography of Anoxic Oxygen Minimum Zones. Proc. Natl. Acad. Sci. 2012, 109 (40), 15996-16003. https://doi.org/10.1073/pnas.1205009109.

(89) Bru, D.; Sarr, A.; Philippot, L. Relative Abundances of Proteobacterial Membrane-Bound and Periplasmic Nitrate Reductases in Selected Environments. Appl. Environ. Microbiol. 2007, 73 (18), 5971-5974. https://doi.org/10.1128/AEM.00643-07.

(90) Smith, C. J.; Nedwell, D. B.; Dong, L. F.; Osborn, A. M. Diversity and Abundance of Nitrate Reductase Genes (NarG and NapA), Nitrite Reductase Genes (NirS and NrfA), and Their Transcripts in Estuarine Sediments. Appl. Environ. Microbiol. 2007, 73 (11), 36123622. https://doi.org/10.1128/AEM.02894-06.

(91) Dong, L. F.; Smith, C. J.; Papaspyrou, S.; Stott, A.; Osborn, A. M.; Nedwell, D. B. Changes in Benthic Denitrification, Nitrate Ammonification, and Anammox Process Rates and Nitrate and Nitrite Reductase Gene Abundances along an Estuarine Nutrient Gradient (the Colne Estuary, United Kingdom). Appl. Environ. Microbiol. 2009, 75 (10), 31713179. https://doi.org/10.1128/AEM.02511-08.

(92) Chen, Y.; Wang, F.; Xu, J.; Mehmood, M. A.; Xiao, X. Physiological and Evolutionary Studies of NAP Systems in Shewanella Piezotolerans WP3. ISME J. 2011, 5 (5), 843-855. https://doi.org/10.1038/ismej.2010.182.

(93) Heylen, K.; Keltjens, J. Redundancy and Modularity in Membrane-Associated Dissimilatory Nitrate Reduction in Bacillus. Front. Microbiol. 2012, 3. https://doi.org/10.3389/fmicb.2012.00371.

(94) Kiss, H.; Lang, E.; Lapidus, A.; Copeland, A.; Nolan, M.; Glavina Del Rio, T.; Chen, F.; Lucas, S.; Tice, H.; Cheng, J.-F.; Han, C.; Goodwin, L.; Pitluck, S.; Liolios, K.; Pati, A.; Ivanova, N.; Mavromatis, K.; Chen, A.; Palaniappan, K.; Land, M.; Hauser, L.; Chang, Y.-J.; Jeffries, C. D.; Detter, J. C.; Brettin, T.; Spring, S.; Rohde, M.; Göker, M.; Woyke, T.; Bristow, J.; Eisen, J. A.; Markowitz, V.; Hugenholtz, P.; Kyrpides, N. C.; Klenk, H.-P. Complete Genome Sequence of Denitrovibrio Acetiphilus Type Strain (N2460T). Stand. Genomic Sci. 2010, 2 (3), 270-279. https://doi.org/10.4056/sigs.892105.

(95) Rusmana, I.; Nedwell, D. B. Use of Chlorate as a Selective Inhibitor to Distinguish Membrane-Bound Nitrate Reductase (Nar) and Periplasmic Nitrate Reductase (Nap) of Dissimilative Nitrate Reducing Bacteria in Sediment. FEMS Microbiol. Ecol. 2004, 48 (3), 379-386. https://doi.org/10.1016/j.femsec.2004.02.010. 